Although family health services authorities encourage and support women entrants to general practice, they may need to play a more active part in monitoring women's workload and share of partnership income. Authorities could determine how many minimum full time practitioners previously working 20 hours a week are now working 26 hours for the same share of the profits, how many now do night work, and whether they treat applications for job sharing in singlehanded practices equally.

The Royal College of General Practitioners supports continued education in the early years in general practice. Doctors on retainer schemes and those returning after a break from full clinical responsibility may have special educational needs, particularly regarding practice management. This group may have low incomes, and meeting their needs may require additional grants. Women are an asset to general practice. The profession, the government, and the family health services authorities have a responsibility to ensure that they are treated equally.

Regional Adviser in General Practice,

Department of Postgraduate Medical Studies,

Gateway House, Piccadilly South,

Manchester M60 7LP

1 Osler $\mathrm{K}$. The employment experiences of a group of vocationally trained doctors. BMY 1991;303:000-00

2 Hooper J, Millar J, Schofield P, Ward G. Part-time women general practitioners-workload an remuneration. I $R$ Coll Gen Pract 1989:39:400-3.

Wilkin D, Hallam L, Leavey R, Metcalfe D. Anatomy of urban general practice. London: Tavistock, 1987.

4 Secretaries of State for Health, Wales, Northern Ireland, and Scotland. Working for patients. London: HMSO, 1989. (Cmnd 555.)

Gray J. The effect of the doctor's sex on the doctor-patient relationship. $\mathcal{F} R$ Coll Gen Prac 1982;32:167-9.

Preston-Whyte ME, Fraser R, Beckett JL. Effect of a principal's gender on consultation pattern fR Coll Gen Pract 1983;33:654-8.

Royal College of General Practitioners. 1990 Members reference book. London: Sabrecrown, 1990.

8 Allen I. Doctors and their careers. London: Policy Studies Institute, 1988.

9 Royal College of General Practitioners. Quality in general practice. London: RCGP, 1985.

\title{
WIST-ful thinking
}

\section{An unsuitable job for a woman}

Only one per cent of consultant general surgeons are women. There are two reasons for this according to Isobel Allen's survey of doctors and their careers. ${ }^{2}$ The first is that surgery is thought to need a full time commitment, which women either cannot or do not want to give. The second is that male surgeons are prejudiced against female doctors.

It would be nice to think that the Women in Surgical Training Scheme (WIST), a joint venture from the Department of Health and the Royal College of Surgeons of England, might increase the numbers of women surgeons. ${ }^{3}$ Its two objectives: to "help women overcome the obstacles... in surgical training" and "to ensure that women are... fully represented at the highest levels in those specialities which have up to now been extensively male dominated" are clearly desirable for women surgeons. The royal college has already removed one obstacle by stating that there is no bar to part time training. The Department of Health aims to increase the number of part time career registrar posts fourfold over the next five years. ${ }^{4}$ Twenty two posts will be available in general surgery. Now that women make up half the entrants to medical schools these objectives are not only desirable for women surgeons but also essential for surgery to attract the best trainees.

So what does this scheme intend to do for women? The Department of Health has provided only $£ 30000$, and WIST's proposed help is more spiritual than practical. ${ }^{5}$ The scheme will target women who have passed the first part of their primary fellowship and encourage and monitor their careers through the appointment of regional advisors. It will encourage mutual support groups. "Ultimately ... the outcome should be an increased representation of women in surgery at consultant level." But in the meantime another generation of women surgeons may be lost.

It seems short sighted to target women at senior house officer level when they are already underrepresented in surgery. Women make up only $13 \%$ of general surgical senior house officers compared with $35 \%$ of those in anaesthetics. ${ }^{6}$

In America - where again only $1 \%$ of surgical chiefs are women-women are put off surgery at medical school. ${ }^{7}$ Surgery is seen to have the most advantages for men-drama and respect-and the most disadvantages for womenirregular hours and prejudice. ${ }^{8}$ In the United Kingdom Isobel Allen found that students frequently used the word "humi- liating" to describe their encounters with surgeons.

If the Royal College of Surgeons of England seriously wants to help women it should look at the obstacles which exist for men. Surgical training is protracted and haphazard. The hours are incompatible with a normal social life. For a woman to succeed she must give up most of the things which other women have. Success for women in surgery is linked to marrying late - if at all - and childlessness. Men at least have wives.

Part time training is not the answer for either sex. The PM(79)3 scheme for part time senior registrar posts has operated in various forms for 20 years, but the first part time senior registrar in general surgery was only recently appointed. There are 10 in ophthalmology. General surgeons still think that part time training means a less than full time commitment. For women with children the pay barely covers the cost of childcare. The hours are still over 40 a week.

The way to attract women into surgery is to improve the lot of both sexes. It is to structure training and complete it within a defined time. For the sake of family life it should be more geographically secure. Hospitals should provide crèches. Hours must continue to be reduced. But none of this will work unless surgeons change themselves. They must stop perpetuating the myth that you have to be big and strong to do surgery. They must stop asking women discriminatory questions at interviews. ${ }^{9}$

WIST may alleviate the feeling of isolation that many women training in surgery feel. It may provide women with patronage from the handful of women who have "made it." What it must not do is monitor women for 20 years only to tell us what we know already.

Editorial registrar,

LUISA DILLNER $B M \mathcal{F}$

1 Medical and dental staffing prospects in the NHS in England and Wales 1989. Health Trends 1990;22:96-103

2 Allen I. Doctors and their careers. London: Policy Studies Institute Blackmore Press, 1988.

3 Joint Working Party. Women doctors and their careers. London: Department of Health, 199

4 Department of Health. Part time opportunities for doctors in training. London: DoH, 1991

5 Department of Health. Women doctors and their careers. London: Department of Health, 1991. (Press release Jan 22.)

6 Medical manpower census of the Department of Health for 30 Sept 1990. London: DoH, 1991 (Prepared for WIST conference Sept 1991.)

Delessardri K. The surgical workforce and women surgeons. Fournal of the American Medical Women's Association 1988;43:169-77.

8 Ramos S, Feiner C. Women surgeons: A national survey. Fournal of the American Medical Women's Association 1989;44:21-5.

9 Allen I, ed. Discussing doctors' careers. London: Policy Studies Institute, 1988. 